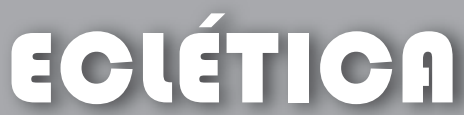 química
}

\section{ADSORPTION ISOTHERM STUDIES OF BOD, TSS AND COLOUR REDUCTION FROM PALM OIL MILL EFFLUENT (POME) USING BOILER FLY ASH}

\author{
IGWE, J.C. ${ }^{*}$, ONYEGBADO C.O. ${ }^{2}$ AND ABIA A.A ${ }^{3}$. \\ ${ }^{1}$ Department of Industrial Chemistry, Abia State University, P.M.B. 2000, Uturu, Abia State-Nigeria. \\ ${ }^{2}$ Department of Chemical Engineering \\ ${ }^{3}$ Department of Pure and Industrial Chemistry, University of Port Harcourt, Choba Uniport, River State - Nigeria \\ *Corresponding Author E-mail: jcigwe2001@yahoo.com. Phone: 234-803-675-2059
}

\begin{abstract}
Palm oil is one of the two most important vegetable oils in the world's oil and fats market. The extraction and purification processes generate different kinds of waste generally known as palm oil mill effluent (POME). Earlier studies had indicated the possibility of using boiler fly ash to adsorb impurities and colour in POME treatment. The adsorption treatment of POME using boiler fly ash was further investigated in detail in this work with regards to the reduction of BOD, colour and TSS from palm oil mill effluent. The amount of BOD, colour and TSS adsorbed increased as the weight of the boiler fly ash used was increased. Also, the smaller particle size of $425 \mu \mathrm{m}$ adsorbed more than the $850 \mu \mathrm{m}$ size. Attempts were made to fit the experimental data with the Freundlich, Langmuir and Dubinin-Radushkevich isotherms. The $\mathrm{R}^{2}$ values, which ranged from 0.8974-0.9898, 0.8848-0.9824 and 0.6235-0.9101 for Freundlich, Langmuir and Dubinin-Radushkevich isotherms respectively, showed that Freundlich isotherm gave a better fit followed by Langmuir and then Dubinin-Radushkevich isotherm. The sorption trend could be put as BOD > Colour > TSS. The apparent energy of adsorption was found to be 1.25, 0.58 and $0.97(\mathrm{KJ} / \mathrm{mol})$ for BOD, colour and TSS respectively, showing that sorption process occurs by physiosorption. Therefore, boiler fly ash is capable of reducing BOD, Colour and TSS from POME and hence could be used to develop a good adsorbent for POME treatment.
\end{abstract}

Keywords: Adsorption, Wastewater, Isotherm, Boiler fly ash, POME.

\section{INTRODUCTION}

The palm oil is of tremendous economic and social importance in Nigeria. The palm oil industry apart from being a major foreign exchange earner for Nigeria in the past has also been identified as a great source of water and land pollution. According to Majid et al, (1999) [1], Palm oil mills produce crude palm oil and palm kernel as their main products. The milling process also generates considerable amounts of co-products/ waste such as empty fruit bunches (EFB), palm oil mill effluent (POME), palm fiber and palm shell. The palm oil mill effluent, the final liquid discharged after extracting the oil from the fresh fruit bunch, contains soil particles, residual oils and suspended solids but only $5 \%$ of dry matters. Palm oil sludge is the material that remains after decanting the palm oil mill effluent. Both the effluent and sludge pollute streams, rivers or surrounding land when discharged without proper treatment. These effluents cause serious depletion of dissolved oxygen and kill fish, prawns and crabs, which are important sources of food and nutrients. 
The effluent discharged from an oil mill is still objectionable and the situation in many countries is quite different and much attention has The subject of effective disp The quantity of POME produced is about $60 \%$ for every tonne of fresh fruit bunches (FFB) processed [3]. Apart from the sludge water itself, which amounts to about $300 \mathrm{~kg}$ per tonnes of bunches milled (or about 1.5 tonnes per tonne of palm oil), there are also about $175 \mathrm{~kg}$ of sterilizer condensate and between 40 and $140 \mathrm{~kg}$ of effluent from hydro cyclone or clay bath separators per tonne of bunches [4]. The total amount of effluent is therefore more than half a tonne per tonne of bunches or 2.5 tonnes per tonne of oil produced in a typical mill [5]. Hence, an average of 30 tonne FFB per hou [5]. Hence, an average of 30 tor in a typical mill will generate about 18 tonnes of effluent per hour. In milling 20 tonnes of bunches per hour, more than 200 tonnes of effluent may be discharged over 24 hours and this may contain up to a tonne of oil and 9 tonnes of dissolved or suspended solids. This effluent has a biochemical oxygen demand (BOD) of about $20,000 \mathrm{mg} / \mathrm{L}$ or $20 \%$ for 5 days, which is extremely high.

Fibre and shell are termed as by-products of the oil mill and they are used as boiler fuel to roduce steme for electricity genetion for the pill and domestic consumption within the mill mill and domestic consunption within the mill complex. Boiler hy ash is produced in paln oil mills from the burning of the fiber and shell. Every tonne of FFB produces about $4 \mathrm{~kg}$ to $6 \mathrm{~kg}$ of boiler ash. This porous ash, which contains about $0.28 \%-1.33 \%$ phosphorus, $1.02 \%-4.31 \%$ potassium, $0.39 \%-3.24 \%$ calcium and $0.29 \%-2.60 \%$ magnesium [6], can be used as a soil conditioner. Currently, this under utilized waste is mainly used as landfill.

Adsorption of heavy metals from aqueous solution by fly ash from palm oil mill and other sources has been reported [7-12]. In view of the maximizing waste utilization and with the prospect of Federal Environmental Protection Agency (FEPA) imposing more stringent BOD limits on palm oil mill, an adsorption method using boiler fly ash may need to be introduced. Therefore, in this study, we investigated the use of boiler fly ash for the reduction of biochemical oxygen demand (BOD), Total suspended solid (TSS) and colour from palm oil mill effluent (POME). Also, adsorp-

tion isotherms were used to correlate and model the adsorption studies.

\section{MATERIALS AND METHODS}

\section{Materials}

Samples of effluent water were collected from a palm oil mill in Okigwe, Imo State Nigeria Boiler fly ash was also collected from the (all (a) ther purification.

\section{METHODS}

\section{Sample Collection and Adsorbent Preparation}

Samples of effluent water were collected in different containers of about 5 liters in volume. The containers were properly washed and rinsed with the effluent before collection to avoid contamination and dilution. The containers were labeled showing time of collection and temperature at collection.

Boiler fly ash was also collected from the same will. To do this, a large quantity was collected using polyethylene bags. The boiler fly ash was first washed with distilled water and then air-dried. The particle size distribution was determined using a Fritsch sieve shaker. This properly sieved the boiler fly ash into two particular mesh sizes of $425 \mu \mathrm{m}$ and $850 \mu \mathrm{m}$ for the purpose of the experiment. Therefore, two samples of boiler fly ash were obtained and placed in different sample containers and labeled according to their mesh sizes $(425 \mu \mathrm{m}$ and $850 \mu \mathrm{m})$. The specific surface are of the fly ash was determined using the methylene blue absorption test (MBT) method des blue absorption test (MBT) method described by tent of the sample was measured by heating the fly ash in an oven at $135^{\circ} \mathrm{C}$ for two hours [1]. The fly ash was activated by soaking in dilute $(2 \% \mathrm{v} / \mathrm{v})$ HNO over night. It was then rinsed with distilled water and air dried, ready for the experimis. led water and air died, in The reason for soaking in nittic acid was to was off soluble contaninants and activate the boiler fly ash by opening up the pores in readiness for sorption process.

\section{Determination of Specific Surface Area $\left(S_{A x}\right)$}

The specific surface area of the adsorben was determined using the methylene blue absorption test (MBT) method [13]. 2.0g of each adsorbent was suspended in $200 \mathrm{~mL}$ of deionized water and 10ppm of methylene blue solution was added to the adsorbent suspension and agitated in a shaker for $2 \mathrm{~h}$. There after, it was kept for 24

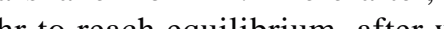

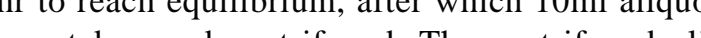
was taken and centrifuged. The centrifuged aliquot was then analyzed using a UNICAM - 87OO UV/Visible spectrophotometer to determine the amount of methylene blue that remained in solution. Also, 20, 30, 40, 50, 60 and 70 ppm solution of methylene blue were then added sequentially and the previous steps repeated. A graph of concentration of methylene blue added versus the amount of absorbed methylene blue (not shown) was used to identify the point. The specific surface area was calcula ce area was calculated from the anount of absorbed methylene ble at the optimum po replacement as follows:

Specific surface area $\left(\mathrm{m}^{2} \mathrm{~g}^{-1}\right)=$ mMB x Av x AMB / (319.98) x (1/ Ms)

Where;

$\mathrm{mMB}=$ Amount of methylene blue absorbed a the point of complete cation replacement. Ms $=$ Mass of adsorbent $\mathrm{Av}=$ Avogadro's number, $6.02 \times 10^{23}$

$\mathrm{AMB}=$ Area covered by one methylene blue (assumed to be $130 \AA^{2}$ )
Sorption Experiments

\section{Effect of weight of fly ash}

The adsorption experiments were conducted in a batch system by preparing various amounts of fly ash $(10,30,40$ and $60 \mathrm{~g})$ of the two different mesh sizes in series of $300 \mathrm{ml}$ wastewater. The various mixtures of fly ash and wastewater were allowed to stand with continuous stirring for 60 mins contact time, at a constant temperature of $30^{\circ} \mathrm{C}$ and $\mathrm{pH}$ of 6.4. After the contact time of 60 mins had elapsed, the mixture was centrifuged at $3000 \mathrm{rpm}$ and the supernatant analyzed for BOD, TSS, colour and $\mathrm{pH}$ by the same methods described below.

A control sample was prepared by filtering the wastewater without the fly ash. The filtrates were then analyzed for BOD, TSS, and colour as described later. The reductions of these parameters as consequence of adsorption were calculated by difference in the initial concentrations and that remaining in the filtrates.

\section{Effect of Initial Concentratio}

To investigate the effect of initial concentration of the wastewater on the adsorption process, various initial concentrations were obtained by diluting the wastewater with distilled water. Initial concentrations of $10 \%, 30 \%, 40 \%, 50 \%$, $60 \%$ and $70 \%$ were used. 30 grams of the boiler fly ash of $800 \mu \mathrm{m}$ size was put into $300 \mathrm{ml}$ wastewate of different concentrations and allowed to stand with continuous stirring for 60 minutes contac time. After 60 minutes contact time, the mixtures were centrifuged at 3000rpm for 10 mins and the $\mathrm{pH}$ by the same methods described below. 
$850 \mu \mathrm{m}$ and $280.6 \mathrm{~m}^{2} \mathrm{~g}^{-1}$ for $425 \mu \mathrm{m}$. The fly ash was found to have moisture content of $1.7 \%$.

The $\mathrm{pH}$ of the solution was determined using $\mathrm{pH}$ meter (HACH 51750 - 60) [14]. The $\mathrm{pH}$ meter was first standardized using a buffer solution of about 7.0 and then the other solutions were analyzed for their various $\mathrm{pH}$ values.

All samples were analyzed for the other parameters as described in the standard methods for the Examination of water and wastewater [15] and standard methods for water and effluents analysis [16].

\section{RESULTS AND DISCUSSION}

The particle sizes of the fly ash used were $450 \mu \mathrm{m}$ and $850 \mu \mathrm{m}$. The specific surface area of the boiler fly ash calculated from the methylene blue absorption test method was $241.4 \mathrm{~m}^{2} \mathrm{~g}^{-1}$ for

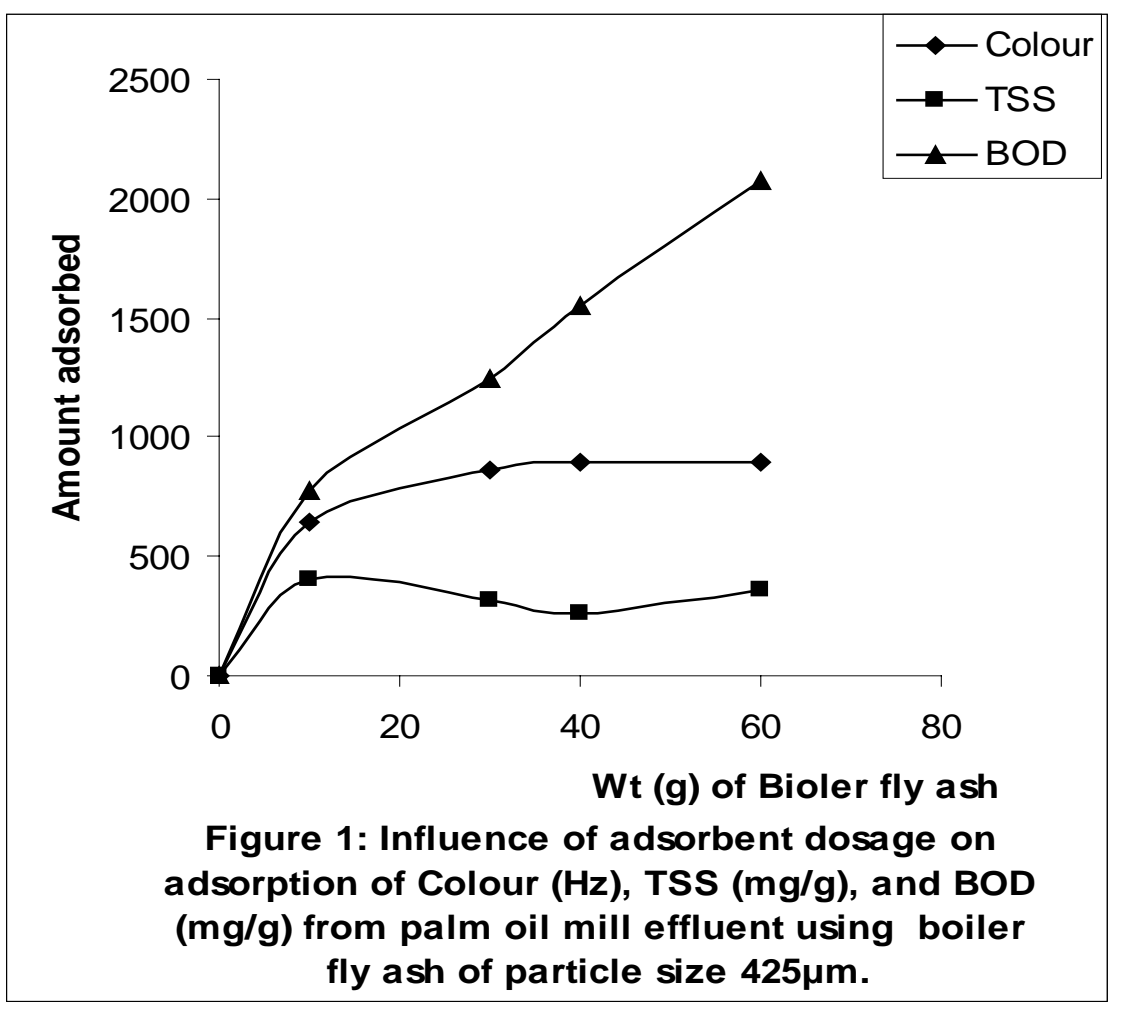
ve removal of BOD, colour and TSS using boile effluent was found to be 6.4. The amount adsorbed was calculated from equation (2) below: $\mathrm{qe}=\mathrm{Co}-\mathrm{Ce}$

here $\mathrm{qe}$ is the amount adsorbed in $\mathrm{mg} / \mathrm{g}$ for BOD and 15 is the initial concentration and $\mathrm{Ce}$ is the reside amount (concentration) after sorption process

Figure 1 shows the amount adsorbed for BOD, colour and TSS from POME as weight (g) of boiler flay ash was varied for particle size of $425 \mu \mathrm{m}$, while that for particle size of $850 \mu \mathrm{m}$ is shown on Figure 2 fly ash are presented. The $\mathrm{pH}$ of the palm oil mill

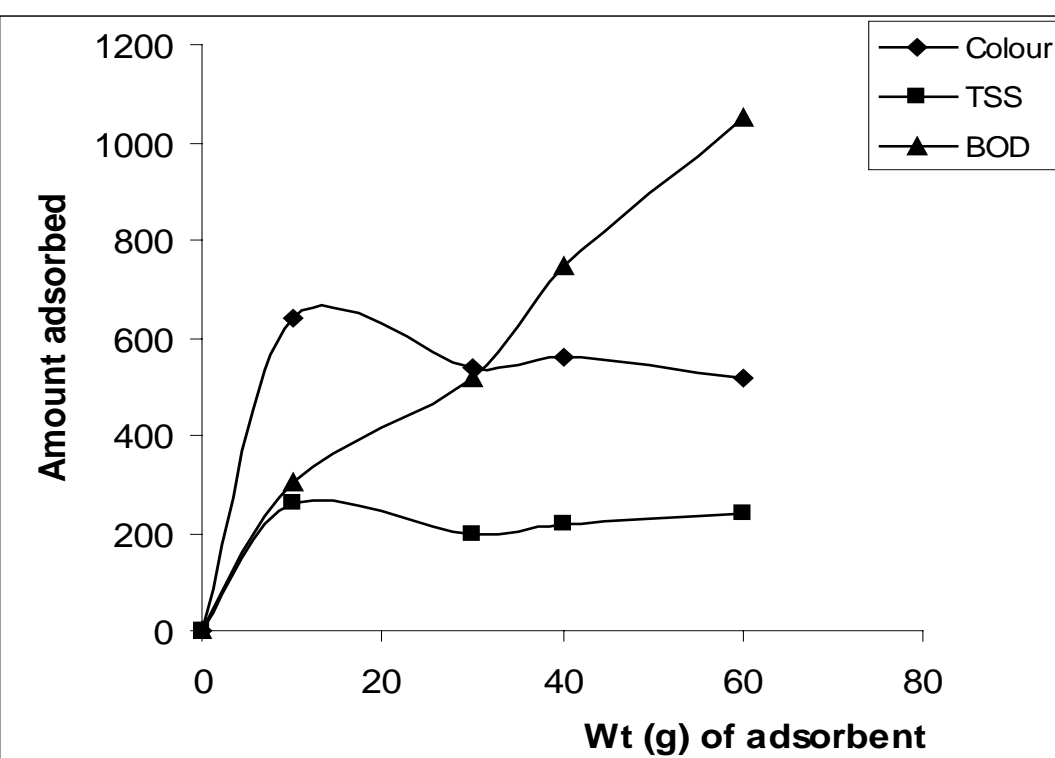

Figure 2: Influence of adsorbent dosage for adsorption of Colour $(\mathrm{Hz})$, TSS $(\mathrm{mg} / \mathrm{g})$ and BOD $(\mathrm{mg} / \mathrm{g})$ from palm oil mill effluent using boile fly ash of particle size $850 \mu \mathrm{m}$.

From these figures, it can be seen that for BOD, both for $425 \mu \mathrm{m}$ and $850 \mu \mathrm{m}$ sizes of boiler fly ash, the amount adsorbed increased steadily as the weight of fly ash was increased. For TSS there are little changes and for colour $(850 \mu \mathrm{m}$ particle size), the amount sorbed decreased as the amoun of fly ash increased. Also, it can be seen that particle size of $425 \mu \mathrm{m}$ gave higher sorption capacity than particle size of $850 \mu \mathrm{m}$.

The amount adsorbed as initial concentration increased for TSS, BOD and colour is shown on Figure 3. In each case, the amount adsorbed increased as the initial concentration of each of the parameters increased. The amount of BOD adsorbed was higher followed by colour and then adsorbed was higher followed by colour and the TSS. The linear regression equations for each of
the parameters and the regression coefficient are shown as equations 3,4 , and 5 for BOD, colour and TSS respectively. It could be seen that all the $\mathrm{R}^{2}$ values are high showing good correlation. The $\mathrm{R}^{2}$ value for TSS was highest, followed by BOD and then that for colour. 


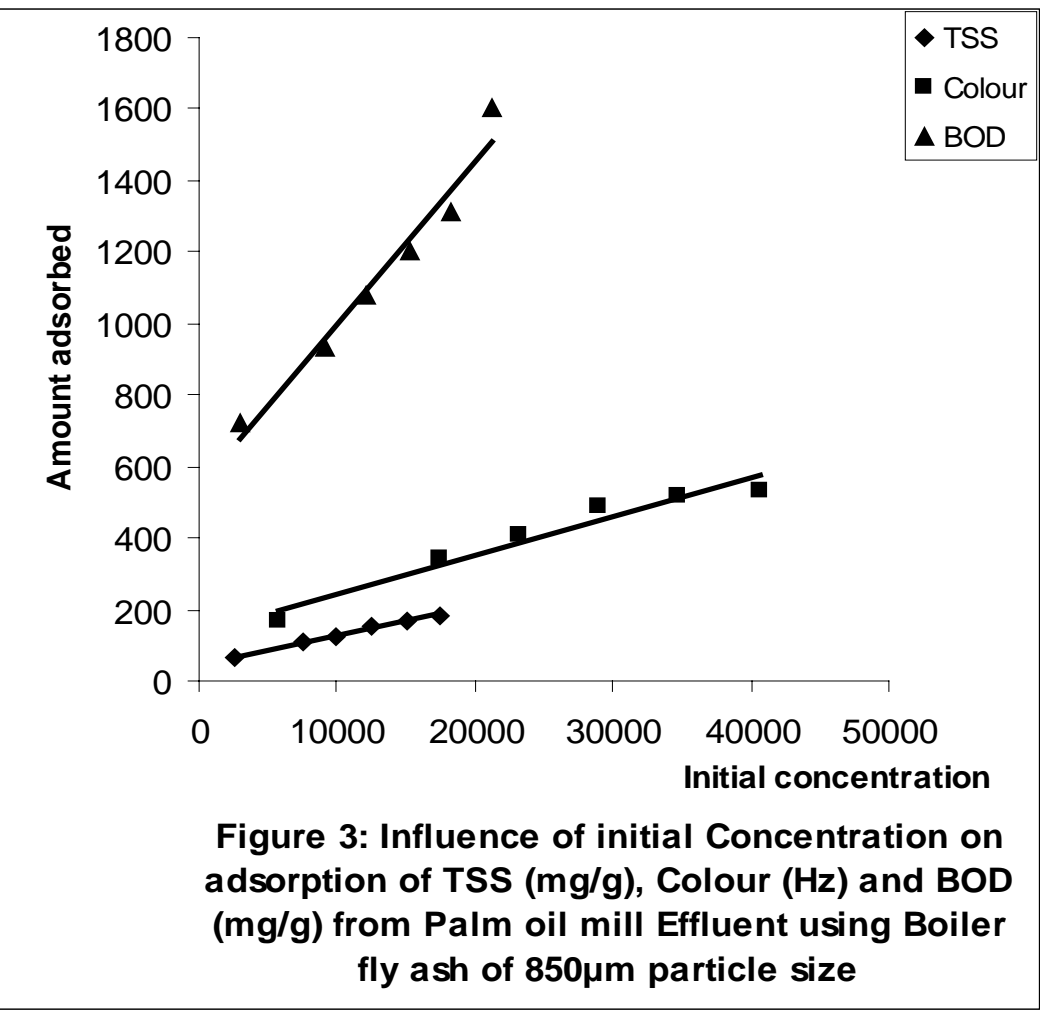

$y=0.0458 x+536.43 \quad\left(R^{2}=0.9668\right)$

$\mathrm{y}=0.0108 \mathrm{x}+137.5 \quad\left(\mathrm{R}^{2}=0.9422\right)$

$y=0.0081 x+46.571 \quad\left(R^{2}=0.9962\right)$

The amount adsorbed against the percentage of wastewater for BOD, colour and TSS from palm oil mill effluent using boiler fly ash is shown on Figure 4. It could be seen that the amount adsorbed increased as percentage of wastewater highest, followed by colour and then TSS.

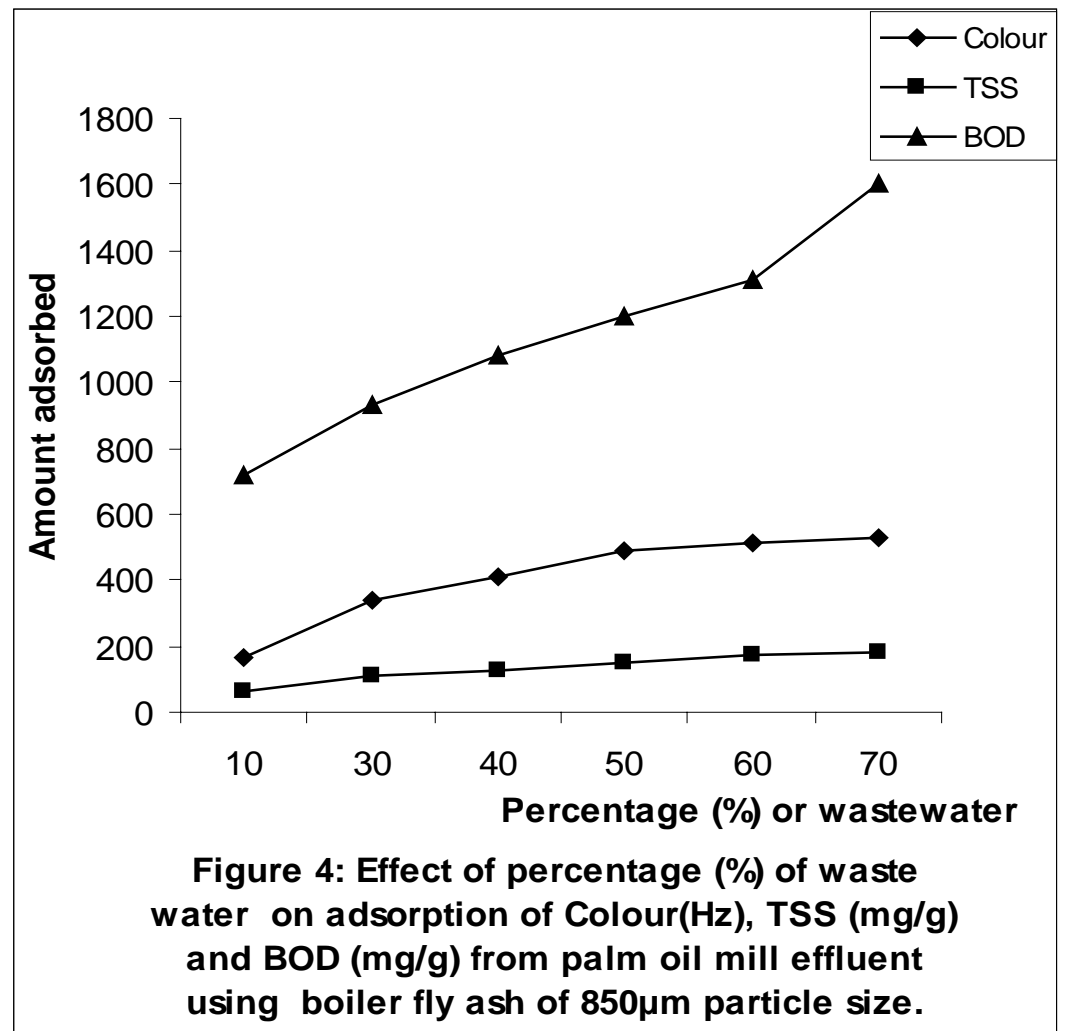

In all, it is clear that the boiler fly ash was capable of reducing the concentrations of BOD, TSS and colour from palm oil mill effluen (POME). The adsorptive removal of these contaminants could be explained based on the modes of sorption of materials or contaminants on absorbents. The adsorptive removal of contaminants could be attributed to two main terms; intrinsic adsorption and coulombic interaction [17]. The coulombic term results from the electrostatc conlon interions betwe eng of in It can also be observed from and adsorbates. It can also be observed from the adsorption of cationic species versus anionic species on adsorbents [17]. The intrinsic adsorption of the materials is determined by their surface areas, which can be observed by the effect of differen sizes of adsorbents. The smaller particle size of $425 \mu \mathrm{m}$ has a higher adsorption. Also, both factors can interact, thereby influencing the adsorption capacity. The specific surface area $\left(\mathrm{S}_{\mathrm{AA}}\right)$ of an adsorbent is the ratio of its surface area to its mass [18]. It has been reported that the surface area has

a great effect on the sorption capacities of adsorbent [19]. Thus, increase in specific surface are increases sorption capacity.

The trend of this sorption capacity could be put as BOD > colour > TSS. This trend could be explained based on solubility and diffusion processes. BOD is defined as the amount of dissolved oxygen needed to break down the carbonaceous component of the waste. This means that BOD involves a dissolved compont of wastewaD Also, colour is a consequence of dissolved compnent of the waste but total suspended solid (TSS) is not. Diffusion the contasion takes place before adsorption of differs diffuse faster than suspended particles, hence will be adsorbed more. Therefore, in our opinion, this is the reason for the sorption trend. The $\mathrm{pH}$ could be seen as a resultant effect of the interactions of the other parameters. That is, changes in $\mathrm{pH}$ of the wastewater are dependent on the changes in the hydrogen ion concention dependent on the dissolved components of the wa- 

is, the $\mathrm{pH}$ scale.

\section{Sorption Isotherm}

When an adsorbent is in contact with the surrounding fluid of a certain composition, adsorption takes place and after a sufficiently long sorption take place and a time, the adsobre ch equilibrium. Generally, an adsorption isotherm is an expression or diagram, which provides information about the fraction of a surface that is covered by adsorbed molecules in equilibrium at constant temperature as a function of pressure or concentration [20]. Adsorption isotherms are described in many mathematical forms, some of which are based on a simplified physical picture of adsorption and desorption, while others are purely empirical relationship in experiment ding expering at most three enpinical parameters, the more the number of empirical parameters, the better the fit between experimental data [21]. Three isotherms; Freundlich, Langmuir and Dubinin-Radushkevich isotherms were chosen to analyze the adsorption process. The Freundlich and Langmuir isotherms are the earliest and simplest known relationships.

$$
\text { The Freundlich isotherm model }
$$

was chosen to estimate the adsorption intensity. It is an empirical equation after Freundlich in 1926, used to describe the isotherm data by;

$\mathrm{Qe}=\mathrm{K}_{\mathrm{F}} \quad(\mathrm{Ce})^{1 / \mathrm{n}}$

Where $\mathrm{K}_{\mathrm{r}}$ and $\mathrm{n}$ are empirical constants [22] Equation (6) may be linearized by taking logarithms as follows:

$\log \mathrm{Qe}=\log \mathrm{K}_{\mathrm{F}}+1 / \mathrm{n} \log \mathrm{Ce}$

Where;

$\mathrm{K}_{\mathrm{F}}=$ Constant in Freundlich isotherm $\mathrm{n}=$ Freundlich exponent

$\mathrm{Ce}=$ Equilibrium liquid phase concentration $\mathrm{Qe}=$ Equilibrium solid phase concentration

The plot of log Qe against log Ce is linear and constants $\mathrm{K}_{\mathrm{F}}$ and $\mathrm{n}$ were evaluated from the intercepts and slopes respectively. The Freundlich isotherm plots are shown on Figure 5 for TSS, BOD and colour. The regression equations and the

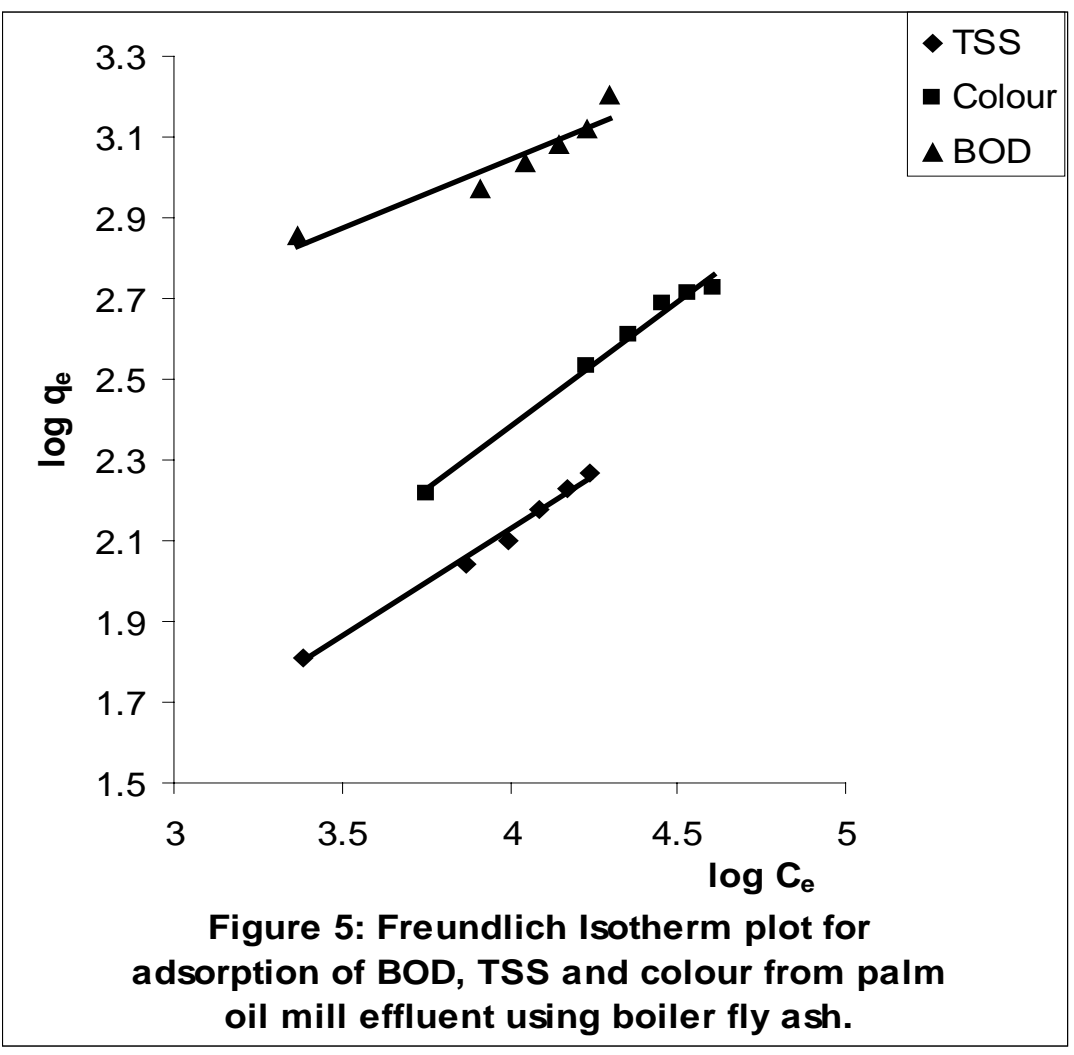

$\begin{array}{ll}y=0.3381 x+1.6912 & R^{2}=0.8974 \\ y=0.6195 x-0.0964 & R^{2}=0.9898 \\ y=0.5315 x+0.0002 & R^{2}=0.9893\end{array}$

intensity. Hence the higher value of $\mathrm{K}_{\mathrm{F}}$ for $\mathrm{BOD}$

$y=0.5315 x+0.0002$

$R^{2}=0.9893$

From these equations and $\mathrm{R}^{2}$ values, it could be seen that the Freundlich equation gave a very good fit to the adsorption process. With $\mathrm{R}^{2}$ value of 0.9898 for colour reduction, which is the highest, it means that the Freundlich isotherm fits the adsortion of colour more, followed by TSS the and and $\mathrm{K}_{\mathrm{F}}$ and n were gen of the Fred ans tan $\mathrm{K}_{\mathrm{F}}$. The Freug Table 1 . The Freundlich exponents $(1 / n)$ are al less than one showing that significant adsorption takes place at low concentration but the increase in the amount adsorbed with concentration becomes less significant at higher concentration and vice versa [22]. Also, $K_{\mathrm{F}}$ and $n$ determines the curvature and steepness of the isotherm [23]. Thus, the higher the $\mathrm{K}_{\mathrm{F}}$ value, the greater the adsorption 
TABLE 1. Adsorption isotherm constants for Freundlich, Langmuir and Dubinin-Radushkevich isotherm for adsorption of BOD, Colour and TSS using boiler fly ash.

\begin{tabular}{ccccc}
\hline \multicolumn{5}{c}{ Fruendlich isotherm } \\
\hline Parameter & $1 / \mathrm{n}$ & $\mathrm{K}_{\mathrm{F}}(\mathrm{L} / \mathrm{g})$ & $\mathrm{R}^{2}$ \\
\hline TSS & 0.53 & 1.00 & 0.9893 \\
Colour & 0.62 & 0.80 & 0.9898 \\
BOD & 0.34 & 49.11 & 0.8975 \\
\hline \multicolumn{5}{c}{ Langmuir isotherm } \\
\hline Parameter & $\mathrm{As}(\mathrm{mg} / \mathrm{g})$ & $\mathrm{K}(\mathrm{L} / \mathrm{g})$ & $\mathrm{R}^{2}$ \\
TSS & 277.78 & $1.0 \mathrm{X} 10^{-4}$ & 0.9118 \\
Colour & 909.09 & $4.29 \times 10^{-5}$ & 0.9824 & \\
BOD & 2000.00 & $1.47 \mathrm{X} 10^{-4}$ & 0.8851 \\
\hline \multicolumn{5}{c}{ Dubinin-Radushkevich isotherm } \\
\hline Parameter & $\beta(\mathrm{KJ} / \mathrm{mol})$ & $\mathrm{q}_{\mathrm{D}}(\mathrm{mg} / \mathrm{g})$ & $\mathrm{E}(\mathrm{KJ} / \mathrm{mol})$ & \\
TSS & 0.82 & 152.81 & 0.06 & 0.8102 \\
Colour & 5.44 & 478.81 & 0.03 & 0.9101 \\
BOD & 0.47 & 1233.24 & 0.02 & 0.6235 \\
\hline
\end{tabular}

The Langmuir equation was chosen for the estimation of maximum adsorption capacity corresponding to complete monolayer coverage on the adsorbent surface. The Langmuir isotherm is represented by the following equation [24];

$\mathrm{qe}=\mathrm{K}_{\mathrm{L}} \mathrm{Ce} /\left(1+\mathrm{a}_{\mathrm{L}} \mathrm{Ce}\right)$

The linearized form of equation (11) could be written as;

$\mathrm{Ce} / \mathrm{qe}=1 / \mathrm{K}_{\mathrm{L}}+\left(\mathrm{a}_{\mathrm{L}} / \mathrm{K}_{\mathrm{L}}\right) \mathrm{Ce}$

Where;

Ce is the equilibrium concentration of the parameter; qe is the amount of parameter adsorbed. The constants $\mathrm{K}_{\mathrm{L}}$ and $\mathrm{a}_{\mathrm{L}}$ are the Langmuir constant (L/g) and Langmuir isotherm constant ( $\mathrm{L} / \mathrm{mg}$ ), respectively. The ratio of $\mathrm{a}_{\mathrm{L}} / \mathrm{K}_{\mathrm{L}}$ represents the maximum adsorption capacity, $\mathrm{Q}_{\max }$. Another form of the Langmuir equation [25], shown below was used to model the adsorption data.

$\mathrm{Ce} / \mathrm{Qe}=1 / \mathrm{KAs}+\mathrm{Ce} / \mathrm{As}$

Where As is the sorbent binding capacity and $\mathrm{K}$ is the binding constant. The plots of $\mathrm{Ce} /$ Qe against Ce gave straight lines and are shown on Figure 6 for TSS, BOD and colour adsorption

on fly ash. The regression equations and the linear coefficient of regression $\left(\mathrm{R}^{2}\right)$ are shown on the plots. The plots and the $\mathrm{R}^{2}$ values show that the Langmuir model gave did not give a very good fit to the sorption process for BOD and TSS. The values of the Langmuir constants are show on Table 1. It is well known that the Langmuir equation is intended for a homogeneous surface. A good fit of this equation reflects monolayer adsorption [22]. the value of the sorbent binding capacity (As).

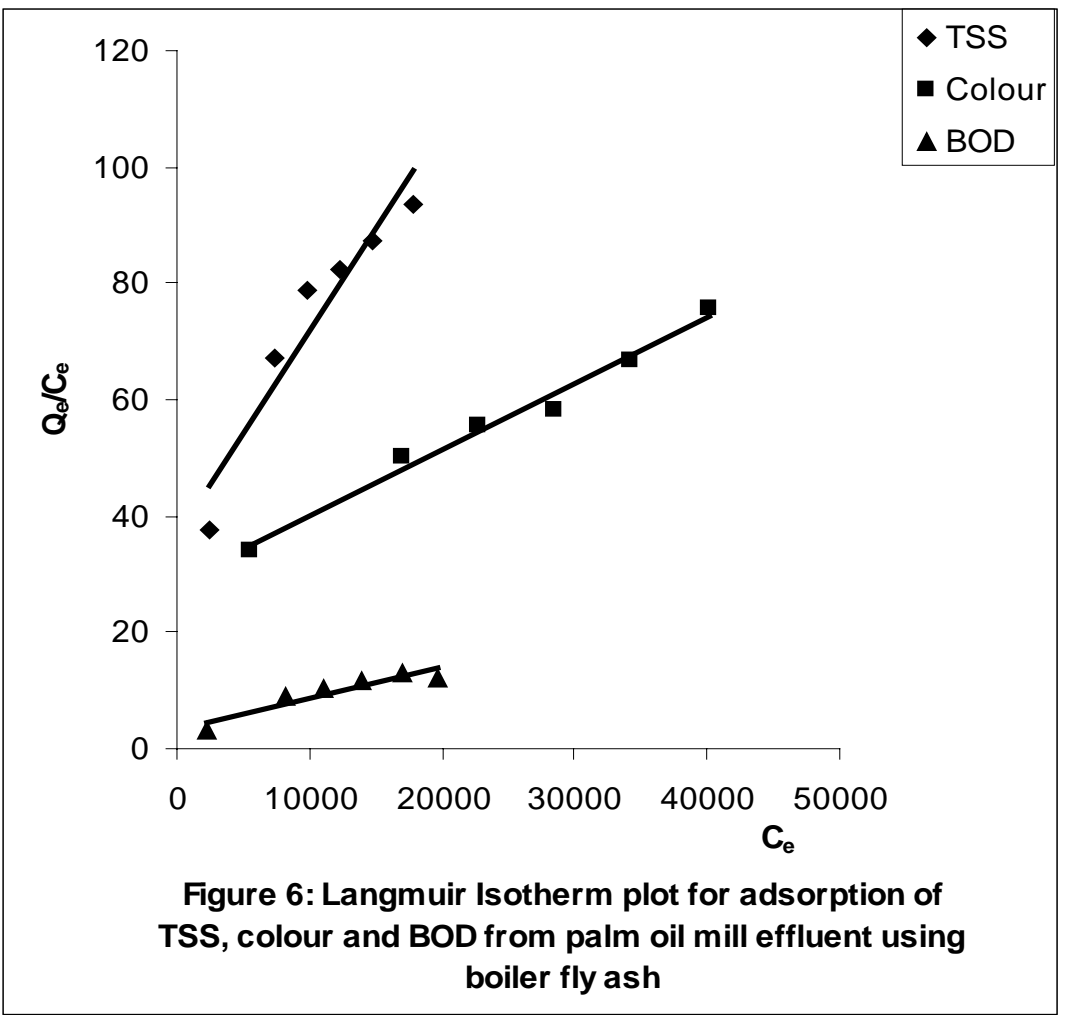

The essential characteristics of the Langmuir isotherm can be expressed in terms of a dimensionless constant separation factor or equilibrium parameter, $\mathrm{R}_{\mathrm{L}}$, which describes the type of isotherm [26] and is defined by the equation (11);

\section{$\mathrm{R}_{\mathrm{L}}=1 /\left(1+\mathrm{K}_{\mathrm{L}} \mathrm{Co}\right)$} isotherm according to Table 2. The $R_{L}$ values were calculated and plotted as shown on Figure 7 . The values of $\mathrm{R}_{\mathrm{L}}$ range from 0.2422 to 0.6911 of BOD; 0.3647 to 0.8009 for colour and 0.3636 to 0.8000 for TSS at various initial concentrations. From Figure 7, it means that the sorption process is favourable 政

\begin{tabular}{cc}
\hline $\mathrm{R}_{\mathrm{L}}$ values & Type of isotherm \\
\hline $\mathrm{R}_{\mathrm{L}}>1$ & Unfavourable \\
$\mathrm{R}_{\mathrm{L}}=1$ & Linear \\
$\mathrm{O}<\mathrm{R}_{\mathrm{L}}<1$ & Favourable \\
$\mathrm{R}_{\mathrm{L}}=\mathrm{O}$ & Irreversible \\
\hline
\end{tabular}




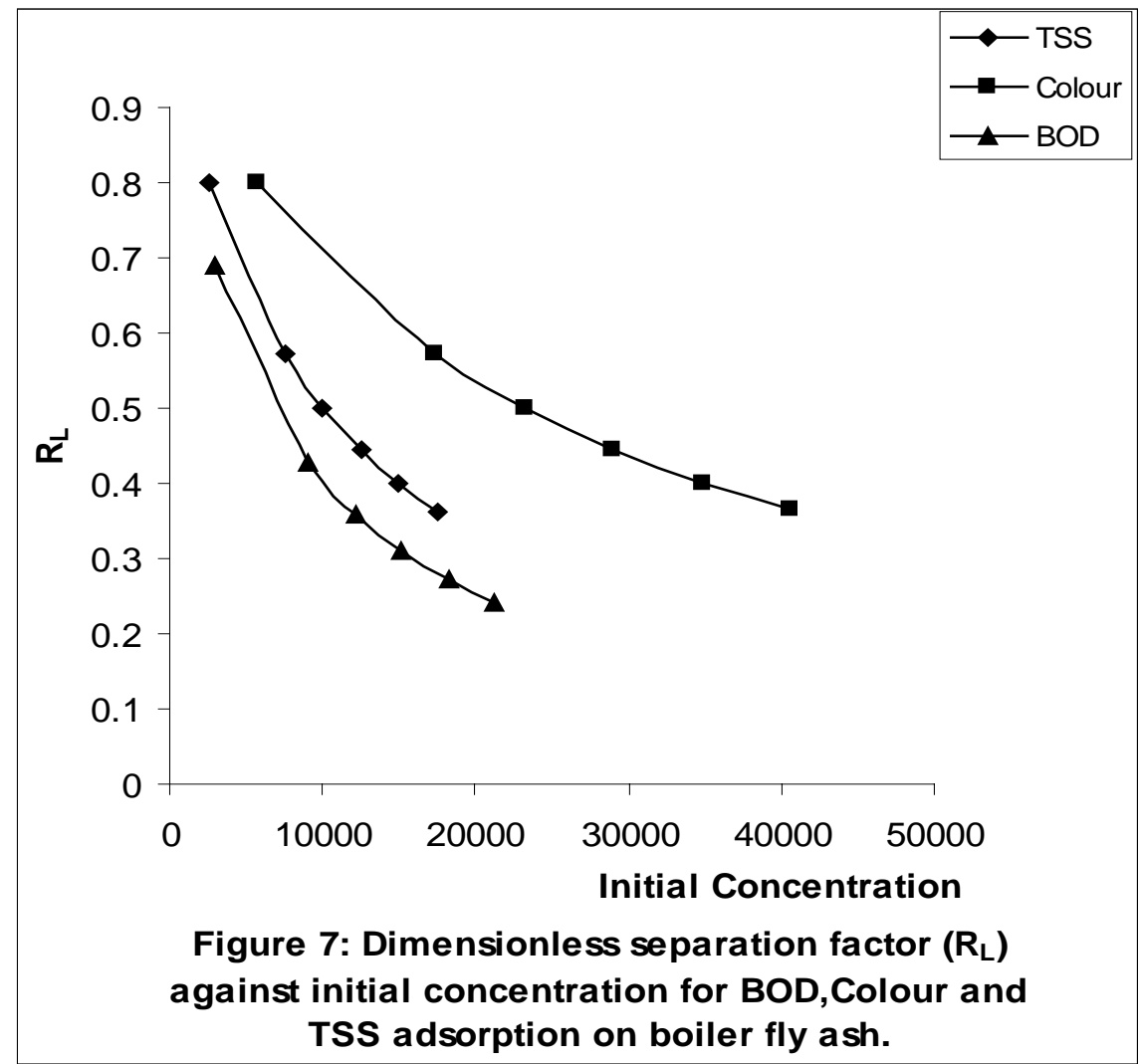

The Dubinin-Radushkevich isotherm was chosen to estimate the characteristic porosity of the fly ash and the model is represented by equation (15) [27];

\section{$\mathrm{qe}=\mathrm{q}_{\mathrm{D}} \exp \left(-\beta\left[\mathrm{RT} \ln (1+1 / \mathrm{Ce}]^{2}\right)\right.$}

Where $\beta$ is related to the free energy of sorption per mole of the sorbate as it migrates to the surface of the adsorbent from infinite distance in the solution and $q_{D}$ is the Dubinin - Radushkevich isotherm constant related to the degree of orbate sorption by the sorbent surface. The linear form of equation (15) is given as;

$\ln \mathrm{qe}=\ln \mathrm{q}_{\mathrm{D}}-\beta \varepsilon^{2}$

Where, $\varepsilon$ is the Polanyi potential $[28,29]$ which is related to the equilibrium concentration

$\varepsilon=\mathrm{RT} \ln (1+1 / \mathrm{Ce})$

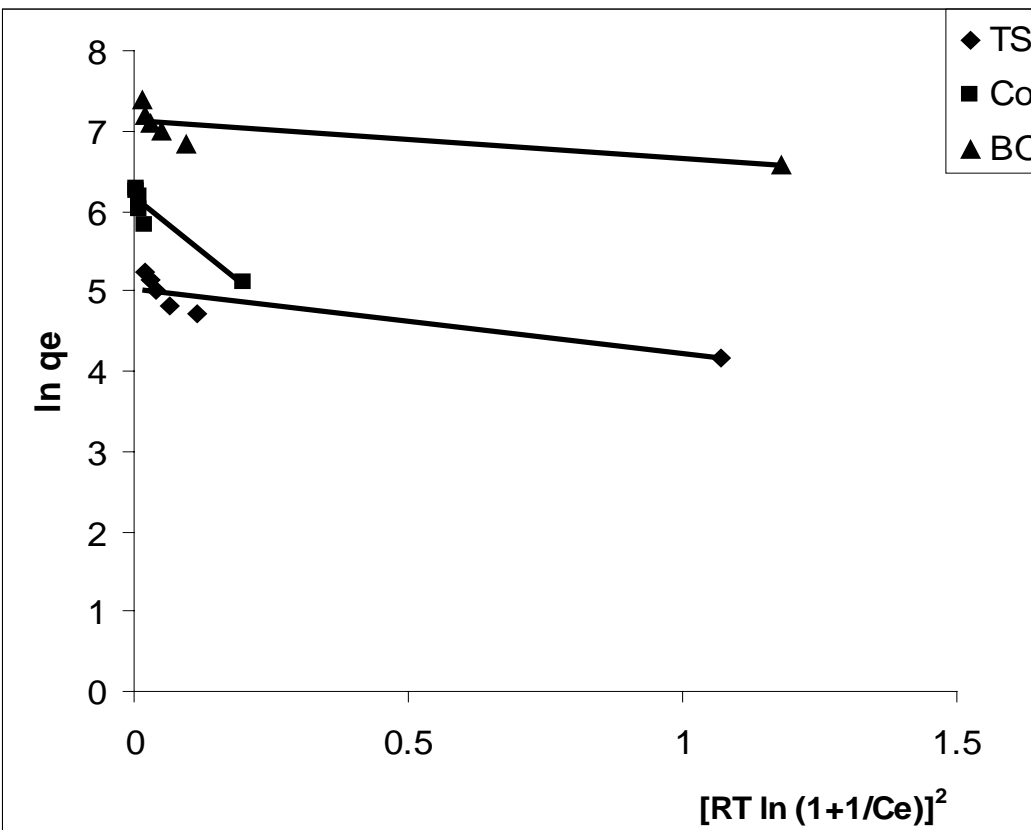

Figure 8: Dubinin-Radushkevich Isotherm plot fo adsorption of TSS, colour and BOD from palm oil mill effluent using boiler fly ash

\section{$\mathrm{E}=1 /(2 \beta)^{1 / 2}$}

From the Dubinin-Radushkevich isotherm, the values of $\mathrm{q}_{\mathrm{D}}$, which is related to the degree of sorbate sorption, shows that BOD has a higher value (1233.24), followed by colour (478.81) and then TSS (152.81). This also shows that the trend of sorption is BOD > colour > TSS. Also, from the value of $\beta$, the appart $>$ TSS. Also, from the value of $\beta$, the apparent 0.03 and $0.02(\mathrm{KJ} / \mathrm{ml})$ for TSS, colone 0.06 , .03 and 0.02 (KJ/Ml) for TSS, colon and BOD respectively showed that the sorption of BOD, colour and TSS are physiosorption process. This is because the values obtained are within the range for physiosorption. Thus, what takes place is physical sorption without chemisorptions. The values of the Dubinin-Radushkevich isotherm constants are also shown on Table 1 , with the $\mathrm{R}^{2}$ values and the apparent energy of adsorption.

\section{CONCLUSION}

Boiler fly ash was utilized as an adsorben for the reduction of BOD, colour and TSS from palm oil will effluent (POME). Adsorption studies were carried out to investigate the effect of weight (g) of fly ash and initial concentration of the effluent. The boiler fly ash was capable of removing BOD, colour and TSS with the efficiency of BOD removal being higher than colour and TSS. The amount adsorbed increased as weight (g) of boiler fly ash was inced. The sorption process was modeled using three soption isothe ms name; Lan process was modeled using three sorption isobini-Radushkevich isotherms. Dubinin-Radushkevich isotherm cannot be used to describe the removal of TSS Colour and BOD by this sorbent. Langmuir isotherm can be used to describe Colour and TSS removal. BOD removal cannot be described by the three isotherm models. Colour removal is when applying the Fre gollich an whe aplying he Frenglich angir models. Generally, from the coefficient of determina- 
tion $\left(\mathrm{R}^{2}\right)$ for the three isotherms, we can compare their fitness to the experimental data as Freundlich $>$ Langmuir $>$ Dubinin-Radushkevich. From the results of this study, it means that boiler fly ash can be used as an adsorbent to further reduce the concentration of BOD, colour and TSS from POME. Therefore, because boiler fly ash is a waste in the palm oil industry, this is a good step in the right direction to industrial waste management.

\section{REFERENCES}

[1] R.A. Majid, A.N Ma and E. Hisham, Palm Oil Research Institute of Malaysia (PORIM) Bulletin, 39, (1999), 1-47.

[2] C.N.S. Hartley, The Oil palm. 3rd Ed. Longman Scientific and Technical U.K., (1988), pp. 14-17.

[3] B.J. Wood, A. review on current methods of dealing with palm oil mill Effluent, Malaysia University Press, Kuala Lumpur, (1989), pp. 19-32.

[4] A.N. Ma, Y Tajima, M. Asahi and J. Hannif, Palm Oil Research Institute of Malaysia (PORIM) Technology, 19, (1996), 1-8.

[5] K.L.Hoe and A.M. Dam, System for palm oil mil effluent Treatment, Ministry of primary industries in Malaysia, (1981), pp. 177-182.

[6] A.M. Rusnani and A.N. Ma, Physical properties of Boiler fly ash from various palm oil mill. PORIM Bulletin 38, (1999), 14-19.

[7] C.B. Behr-Andres and J.N. Hutzler, Journal of Environmental Engineering, 120 (6), (1994), 1488-1506.

[8] M.A. Hashim, K.H. Chu, R. Chitgupa and A.N. Ma, Adsorption of copper by fly ash obtained from oil palm waste: paper presented at the 6th J.S.PS-VCC Seminar, Kyoto University Kyoto, Japan, 27-28 November, (1996).

[9] A. Mathur and D.C. Rupainwar, Asian Environ. 10(3), (1988) 19-25.

[10] K.K. Panday, G.U.R. Prasad, and V.N. Singh, Water Res. 19 (17), (1985), 873.

[11] T.T. Theis, and Wirth, J.L. Environ. Sci. and Technol., 11(12) (1977), 1096-1100.

[12] C.H. Weng and C.H. Huang, Journal of Environmental Engineering, 120 (6), (1994), 1470-1487.

[13] J.C. Santamarina, Klein; Y.H. Wang and E. Prencke, Can. Geotech. J. 39, (2002), 233-241.

[14] J.C. Igwe. Treatment of palm oil mill Effluent (POME) using Boiler fly ash. M.Eng. Thesis, Department of Civil and Environmental Engineering, University of Port Harcourt, River State Nigeria, (2008), pp. 1-163.

[15] APHA, Standard methods for the Examination of water and wastewater. 16th Edition. American Public Health Association, Washington D.C, (1985).
[16] C.M.A. Ademoroti, Standard methods for Water and Effluents Analysis. Foludex Press Ltd. Ibadan, (1996), pp 4454.

[17] S. Gang and S. Weixing. Ind. Eng. Chem. Res., 37(4), (1998), 1324-1328.

[18] A.A. Abia, and E.D. Asuquo. Afr. J. Biotechnol., 5(16), (2006), 1475-1482.

[19] R. Qadeer and S. Akhtar. Turk. J. Chem., 29, (2005), 9599.

[20] W.J. Moore. Basic Physical Chemistry. Prentice-Hall Inc. Eagle Wood U.S.A, (1986), p. 319.

[21] Motoyuki, S. Adsorption Engineering, Elsevier Sci. Publishers, (1990), pp. 5-61

[22] T. Hsisheng and H. Chien-To. Ind. Eng. Chem. Res., 37(9), (1998), 3618-3624.

[23] A. Akgerman and M. Zardkoohi. J. Chem. Eng. Data, 41, (1996), 185-191.

[24] I. Langmuir. J. Am. Chem. Soc. 38, (1916), 2221.

[25] C.A. Eligwe, C.I.A. Nwoko and U.U. Egereonu. J. Chem. Soc. Nig., 24, (1999), 70-76.

[26] N. Ahalya, R.D. Kanamadi and T.V. Ramachandra. Electronic J. Biotechnol., 8(3), (2005), 258-264.

[27] M. Horsfall Jnr; A.I. Spiff and A.A. Abia. Korean Chem. Soc., 25(7), (2004), 969-976.

[28] A. Sari, M Tuzen, O. D.Uluozlu and M. Soylak. Biochem. Eng. J., 37, (2007), 151-158.

[29] L. Fu, J. Wang, H Lu, Y. Su and A. Ren. J. Hazard. Matter, 151, (2008), 851-854. 